\title{
Study on Technology Development and Solvent Suitability for Separation of Essential Lipid from Various Bioresources: A Review
}

\author{
Mohammednur Seid $^{1 *}$, Nuru Ibrahim ${ }^{2}$, Dr. Ravi Kumar Madugula ${ }^{2}$ \\ ${ }^{1,2}$ Department of Chemical Engineering, College of Engineering and Technology, \\ Samara University, Samara, Afar, Ethiopia.
}

\begin{abstract}
The main objective of present study is the solvent suitability as an effective method for the separation of essential lipid from various bio resources. It is very clear from the literature survey that the solvent suitability can be achieved through different solvents such as hexane, methanol, ethyl acetate, liquid Co2. However there is a need to study more on the technology development for separation of essential lipid from bio resources. Hence, this review paper highlights the summary of Separation techniques and lipid extraction methods for removal of lipid from their bioresources.
\end{abstract}

Keywords:- Extraction, Lipids, Micro algae, Macro algae.

\section{INTRODUCTION}

The world energy demand has become a nationwide as well as a global issue and starts to raise serious problem in the form of renewable energy base to satisfy the futuristic demand [1]: now a day, majority of global fuel need is supplied by fossil-based fuels [2]. More use of these fossil fuels are creates serious problems in an energy shortage and impact on the environment [3, 4]. A plant has been familiarity as alternative raw material for biofuels such as bioethanol production [5, 6]. The algal biomass has become a future attractive source for biofuel production [7]. Algal lipids include polar lipids, which are ordinary structural includes phospholipids and glycolipids and neutral lipids [8, 9]. Microalgae are microscopic photosynthetic organisms such as roots, stems, and leaves of higher plants [10]. Macro algae contain the most essential components in the aquatic ecosystems, which are important for the marine bio resources preservation by preventing eutrophication and pollution [11]. Macro algae are generally fast growing and reach size up to $60 \mathrm{~m}$ in length [12]. Prokaryotic and eukaryotic of photosynthetic microorganisms are found in unsuitable conditions due to their unicellular structure unit $[13,14]$.

\section{MATERIALS AND METHODS}

\section{$>$ Pre-treatments of Algae biomass}

Pre-treatment can be applied on the biomass to increase lipid recovery efficiency through breaking the microalgal cell walls. This facilitates easier cellular lipid extraction. There were various methods can be used as pre- treatments such as mechanical, chemical, physical and biological.

\section{$>$ Algae Cultivation:}

The cultivation methods of the microalgae production are commonly used in two ways: The open pond system and close photo bioreactors system. The open pond system was the earliest way to cultivate microalgae. The microalgae samples are put into an open pond with water. The open pond is designed as a paddle wheel to mix and cycle the algae cell. Which is operated in a circulatory mode, then the fresh input transformed towards the paddle wheel to the pond, and then the microalgae can be collected in the cyclic process. The close photo bioreactor system was a close environment to culture microalgae with technological equipment. There were various kinds of photo bioreactors such as Fermentation tank photo bioreactor, Tubular photo bioreactor, Plate photo bioreactor etc.

\section{$>$ Harvesting:}

Harvesting lipid biomass was the separation of biomass from the culture medium. In which process 20-30 percent costs were measured through harvesting process. In some cases, costs percentage from 50 to $90 \%$.

\section{Centrifugation}

Centrifugation was a process for a composition mixture centrifuge to decant by centrifugal force. In centrifugation, gravity force was used for segregation at a much higher rate. Depending on segregation all kinds of micro algae can be segregated.

\section{RESULTS AND DISCUSSION}

\section{$>$ Separation technique:}

The technology pathway was investigated the cultivation of algal biomass by lipid separation to hydrocarbon biofuels. Most of the researchers reported that the lipid extraction from microalgae methods such as physical and chemical methods. Solvent extraction was a most widely used technique with cell disruption techniques to increase the process for improvement yields. Different cell disruption methods were investigated such as autoclaving, osmotic shock, microwave-assisted extraction and sonication-assisted extraction. Table 1 shows the summary of separation techniques. 
ISSN No:-2456-2165

\begin{tabular}{|c|c|c|c|}
\hline Solvent type & Extraction conditions & Cell disruption & References \\
\hline $\begin{array}{c}\text { Hexanes: ethanol (subcritical } \\
\text { co-solvent extraction) }\end{array}$ & $\begin{array}{c}\text { Wet microalgae }\left(-90^{\circ} \mathrm{C}, 1.4 \mathrm{MPa},\right. \\
50 \mathrm{~min})\end{array}$ & None & 15 \\
\hline Methanol: chloroform & $\begin{array}{c}\text { Freeze-dried microalgae }(-10 \mathrm{~min} \\
\text { grinding MP followed by stirring for } 30 \\
\text { min and centrifugation for } 10 \mathrm{~min})\end{array}$ & $\begin{array}{c}\text { Lyophilization prior } \\
\text { Mortar and pestle prior }\end{array}$ & 16 \\
\hline ethyl acetate: methanol & $\begin{array}{c}\text { Freeze-dried microalgae } \\
-25^{\circ} \mathrm{C}\end{array}$ & $\begin{array}{c}\text { Bead-beating and } \\
\text { Lyophilization prior }\end{array}$ & 18 \\
\hline Supercritical $\mathrm{CO}_{2}$ & $\begin{array}{c}\text { Freeze-dried then re-wetted microalgae(- } \\
\left.60 \text { min, } 40 \mathrm{MPa} \text {, and } 60{ }^{\circ} \mathrm{C}\right)\end{array}$ & $\begin{array}{c}\text { Lyophilization prior } \\
\text { Drying under air prior }\end{array}$ & 19 \\
\hline Liquid $\mathrm{CO}_{2}$ & $\begin{array}{c}\text { Freeze-dried microalgae }(-120 \mathrm{~min}, 6.8 \\
\left.\mathrm{MPa} \text {, and } 25^{\circ} \mathrm{C}\right)\end{array}$ & Lyophilization prior & 17 \\
\hline
\end{tabular}

Table 1:- Summary of separation techniques.

\section{Lipid extraction:}

Microalgae lipid extraction was consist of harvesting and dewatering operations. Microalgae lipid stays in the microalgae cell after drying. The lipid extraction was to break the cell wall and cell membrane, then the lipid release from the microalgae cells. Microalgae lipid extracted from different methods as Chemical cool press method, Enzymatic Extraction and Supercritical Fluid Extraction. Table.2. shows the category of lipid extraction methods.

\begin{tabular}{|c|c|}
\hline Extraction methods & Categories \\
\hline Mechanical & $\begin{array}{c}\text { Mechanical cell press, Grinding (with/without cryogens), high speed Homogenizers, } \\
\text { Bead milling/bead beating. }\end{array}$ \\
\hline Chemical & Solvent extractions, Supercritical fluid extraction, Ionic liquids, Osmosis, Oxidation. \\
\hline Biological & Antibiotics, Enzymes (lytic, autolysis). \\
\hline Electromagnetic & Microwaves (with/without solvents), Ultrasound. \\
\hline Thermal & Freeze drying, Autoclave, Steam explosion, Hydrothermal liquefaction. \\
\hline
\end{tabular}

Table 2:- Category of lipid extraction methods.

Chemical Extraction.

Chemical extraction methods were most commonly used organic solvents for extraction process. Chemical extraction was also known as solvent extraction. Solvent extraction was most widely used method for the extraction of oil and fats (lipids). Table.3. shows the summary of solvent extraction techniques.

\begin{tabular}{|c|c|c|c|}
\hline Solvent & Cell disruption & Extraction conditions & References \\
\hline 1:1 (v/v) hexane: methanol & $\begin{array}{c}\text { Grinded \& Lyophilization } \\
\text { prior }\end{array}$ & Freeze-dried microalgae for $120 \mathrm{~min}$ & [20] \\
\hline $\begin{array}{c}\text { 3:1 (v:v) hexanes: ethanol } \\
\text { (subcritical co-solvent extraction) }\end{array}$ & None & Wet microalgae for $50 \mathrm{~min}$ & [21] \\
\hline $\begin{array}{c}\text { 2:1 (v:v) methanol: } \\
\text { chloroform }\end{array}$ & Mortar and pestle & $\begin{array}{l}\text { Freeze-dried microalgae } \\
\text { For } 10 \text { min grinding }\end{array}$ & [22] \\
\hline 2:1 (v/v) chloroform: methanol & Grinded \& Dried prior & Dried microalgae for $25^{\circ} \mathrm{C}$ & [23] \\
\hline 2:1 (v:v) chloroform: methanol & Microwave & $\begin{array}{l}\text { Wet microalgae For } 5 \text { min radiation } \\
(500 \mathrm{~W})\end{array}$ & [24] \\
\hline 1:2 (v/v) chloroform: methanol & Spray-dried prior & $\begin{array}{c}\text { Dried microalgae For } \\
25^{\circ} \mathrm{C}\end{array}$ & {$[25]$} \\
\hline $\begin{array}{l}\text { 2:1 (v/v) dichloromethane: } \\
\text { methanol }\end{array}$ & $\begin{array}{l}\text { Ultrasonication and } \\
\text { Microwave }\end{array}$ & $\begin{array}{l}\text { Freeze-dried microalgae } \\
\text { For } 25^{\circ} \mathrm{C}\end{array}$ & [26] \\
\hline $\begin{array}{c}2: 1 \text { (v:v) ethyl acetate: } \\
\text { methanol }\end{array}$ & Bead-beating & $\begin{array}{l}\text { Freeze-dried microalgae } \\
\text { For } 25^{\circ} \mathrm{C}\end{array}$ & [27] \\
\hline $1: 1(\mathrm{v}: \mathrm{v}) \mathrm{CF}_{3} \mathrm{SO}_{3}$ : methanol & Lyophilization prior & $\begin{array}{l}\text { Freeze-dried microalgae } \\
\text { For } 65^{\circ} \mathrm{C}\end{array}$ & [28] \\
\hline
\end{tabular}

Table 3:- Summary of solvent extraction Techniques. 


\section{CONCLUSION}

The extraction of lipid from microalgae can be achieved by an expeller or press, solvent extraction with organic solvents, or supercritical fluid extraction (SCFE). Then after recovering the oil from microalgae, transesterification process is mostly adopted for synthesis of biodiesel. In this review clearly summarized the separation techniques, solvent extraction, and lipid extraction methods.

\section{REFERENCES}

[1]. T.G. Dunahay, E.E. Jarvis, S.S. Dais, and P.G. Roessler, Genetic engineering of Microalgae for fuel production, Appl. Biochem. Biotechnol. 34 (1992) 331-339. http://doi.org/ 10.1007/BF02920556.

[2]. A. Demirbas, F. Demirbas, Importance of Algae Oil as a Source of Biodiesel, Energy Conversion and Management. $53 \quad$ (2011) 163-170. http://doi.org/10.1016/j.enconman.2010.06.055.

[3]. VB. Veljkovic, OS. Stamenkovi, MB. Tasic,The wastewater treatment in the biodiesel production with alkali-catalyzed transesterification, Renewable and Sustainable Energy Reviews. 32 (2014) 40-60.

[4]. Z. Yaakob, BN. Narayanan, S. Padikkaparambil, SK. Unni, MP. Akbar, A review on the oxidation stability of biodiesel, Renewable and Sustainable Energy Reviews. 35 (2014) 136-153.

[5]. C.S. Jones, and S.P. Mayfield, Algae Biofuels Versatility for the Future of Bioenergy, Current Opinion in Biotechnology. 23 (2012) 346-351. http://doi.org/10.1016/j.copbio.2011.10.013

[6]. M. Mubarak, A. Shaija, Suchithra, TV Ultrasonication An effective pre-treatment method for extracting lipid from Salvinia molesta for biodiesel production, Resource efficient technologies. 2(3) (2016) 126-132.

[7]. M. Cooney, G. Young, and N. Nagle, Extraction of bio-oils from microalgae, Sep. Purif. Rev. 38 (2009) 291-325. http://doi.org/ 10.1080/15422110903327919.

[8]. HC. Greenwell, LML. Laurens, RJ. Shields, RW. Lovitt, KJ. Flynn, Placing microalgae on the biofuels priority list a review of the technological challenges, J. R. Soc Interface. (2010) 703-26.

[9]. H. Schuhmann, DK. Lim, PM. Schenk, Perspectives on metabolic engineering for increased lipid contents in microalgae, Biofuels. 3 (2012) 71-86.

[10]. RP. John, GS. Anisha, KM. Nampoothiri, A. Pamdey, Micro and macroalgal biomass a renewable source for bioethanol, Bioresour Technol. 102(1) (2011) 186193.

[11]. M. Notoya, Production of biofuel by macroalgae with preservation of marine resource and environment. (2010).

[12]. D. J. Mc Hugh, A guide to the seaweed industry, FAO Fisheries Technical paper. (2003) No 441, 105.

[13]. Li Y, M. Horsman, Wu N, Biofuels from microalgae, Biotechnology Progress. 24 (2008) 815-20.
[14]. Li Y, B. Wang, Wu N, Effect of nitrogen sources on cell growth and lipid production of Neochloris oleoabundan, Applied Micobiology and Biotechnology.81 (2008) 629-36.

[15]. Mahmoodi, and Nooshin Salman Tabrizi. "Removal of dyes from colored textile wastewater by orange peel adsorbent: equilibrium and kinetic studies." Journal of Colloid and interface Science, 288(2) (2005) 371-376.

[16]. L. Petigny, S. Périno, M. Minuti, F. Visinoni, J. Wajsman, F. Chemat, Simultaneous microwave extraction and separation of volatile and non-volatile organic compounds of boldo leaves, From lab to industrial scale. Int. J. Mol. Sci.15 (2014) 7183-7198.

[17]. S. Balasubramanian, J.D. Allen, A. Kanitkar, D. Boldor, Oil extraction from Scenedesmus obliquus using a continuous microwave system Design, optimization, and quality characterization, Bioresour. Technol.102 (2011) 3396-3403.

[18]. M. Al Hattab, A. Ghaly, Microalgae oil extraction pre-treatment methods Critical review and comparative analysis, J. Fundam. Renew. Energy. Appl.5 (2015), 1-26.

[19]. B. Trusheva, D. Trunkova, V. Bankova, Different extraction methods of biologically active components from propolis, a preliminary study, Chem J. Cent. (2007) 13.

[20]. B. Kaufmann, and P. Christen, Recent extraction techniques for natural products, microwave-assisted extraction and pressurized solvent extraction, Phytochem. Anal. 13(2002) 105-113.

[21]. Kannan, Nagarethinam, and Mariappan Meenakshi Sundaram. "Kinetics and mechanism of removal of methylene blue by adsorption on various carbons-a comparative study." Dyes and pigments, 51 (1) (2001) 25-40.

[22]. F. Chemat, M. Lucchesi, J. Smadja, L. Favretto, G. Colnaghi, F. Visinoni, Microwave accelerated steam distillation of essential oil from lavender a rapid, clean and environmentally friendly approach, Anal Chim Acta. 555 (2006) 157-160.

[23]. N. Bousbia, M. Vian, M. Ferhat, B. Meklati, F. Chemat, A new process for extraction of essential oil from citrus peels, microwave hydrodiffusion and gravity. J Food Eng. 90 (2009) 409-413.

[24]. N. Li, C. Deng, Y. Li, H. Ye, X. Zhang, Gas chromatography-mass spectrometry following microwave distillation and headspace solid-phase microextraction for fast analysis of essential oil in dry traditional Chinese medicine, J Chromatogr A. 1133 (2006) 29-34.

[25]. M. V. Shah, M. C. Rohit, Novel techniques for isolation and extraction of phytoconstituents from herbal plants, Am J Phytomed Clin Ther. 1 (2013) $338-350$.

[26]. J. L. Luque-García, M. D. Luque de Castro, Ultrasound a powerful tool for leaching, Trends Anal Chem. 22 (2003) 41-47.

[27]. R. K. Bhaskaracharya, S. Kentish, M. Ashokkumar, Selected applications of ultrasonics in food processing, Food Eng Rev. 1 (2009) 31-49. 
[28]. E. B. Flint, and K. S.Suslick, The temperature of cavitation, Science 253 (1991) 1397-1399.

[29]. W. B. McNamara, Y. T. Didenko, and K. S. Suslick, Sonoluminescence temperature during multi bubble cavitation, Nature. 401 (1999) 772-775.

[30]. M. Vinatoru, An overview of the ultrasonically assisted extraction of bioactive principles from herbs, Ultrason. Sonochem. 8 (2001) 303-313.

[31]. A. F. Ferreira, A. P. S. Dias, C. M. Silva, and M. Costa, Effect of low frequency ultrasound on microalgae solvent extraction Analysis of products, energy consumption and emissions, Algal. Res 14 (2016) 9-16.

[32]. A. Patist, and D. Bates, Ultrasonic innovations in the food industry from the laboratory to commercial production, Innovat Food Sci Emerg Technol. 9 (2008) 147-154.

[33]. K. Vilkhu, R. Mawson, L. Simons and D. Bates, Applications and opportunities for ultrasound assisted extraction in the food industry- A review, Innov Food Sci Emerg Technol. 9 (2008) 161-169.

[34]. S. Albu, E. Joyce, L. Paniwnyk, P. Lorimer, and J. Mason, Potential for the use of ultrasound in the extraction of antioxidants from Rosmarinus officinalis for the food and pharmaceuticals industry, Ultrasonics Sonochem. 11 (2004) 261-265.

[35]. S. Shah, A. Sharma, and N. Gupta, Extraction of oil from Jatropha curcas (L) seed kernels by combination of ultrasonication and enzymatic oil extraction, Bioresource Technol. 96 (2005) 21-123.34

[36]. J. Dai, R. J. Mumper, Plant phenolics extraction, analysis and their antioxidant and anticancer properties, Molecules. 15 (2010) 7313-7352.

[37]. R. Czechowska-Biskup, B. Rokita, S. Lotfy, P. Ulanski, and J. M. Rosiak, Degradation of Chitosan and starch by 360- KHz ultrasound, Carbo Polymers. 60 (2005) 175-184.

[38]. S. Chemat, A. Lagha, H. AitAmar, V. Bartels, and F. Chemat, Comparison of conventional and ultrasound assisted extraction of carvone and limonene from caraway seeds, Flav Frag. J 19 (2004): 188-195.

[39]. S. Abdullah, S. K. Mudalip, S. M. Shaarani, Pi. NA, Ultrasonication extraction of oil from Monopterus albus effect of different ultrasonic power solvent volume and sonication time, J. Appl. Sci. 10 (2010) 2713-2716.

[40]. X. Huaneng, Z. Yingxin, H. Chaohong, Ultrasonically assisted extraction of isoflavones from stem of Pueraria Lobata (Willd.) Ohwi and its mathematical model, Chin J. Chem. Eng. 15 (2007) 861-867.

[41]. F. Ishtiaq, R. Farooq, A. Farooq, M. Siddique, H. Shah, MU. Hassan, MA. Shaheen, Application of ultrasound in pharmaceutics world, Appl. Sci. J. 6 (2009) 886-893.

[42]. S. S. Handa, S. P. S Khanuja, G. Longo, D.D. Rakesh, Extraction Technologies for Medicinal and Aromatic Plants, Trieste. (2008).

[43]. Q. Li, X. Jiang, Y. He, L. Li, M. Xian, and J. Yang, Evaluationofthebio- compatibleionic liquid1-methyl3-methylimidazoliumdimethylphosphitepre treatment of corncob for improved saccharification, Appl.Microbiol. Biotechnol. 87 (2010) 117-126.

[44]. W. C. Huang, and J. D. Kim, Cationic surfactantbased method for simultaneous harvesting and cell disruption of a microal 7 gal biomass, Bioresour Technol. 149 (2013) 579-581.

[45]. G. Ulloa, C. Coutens, M. Sánchez, J. Sineiro, J. Fábregas, F. J. Deive et al, On the double role of surfactants as microalga cell lysis agents and antioxidants extractants, Green Chem. 14 (2012) 1044-1051.

[46]. N. Tharapiwattananon, J. Scamehorn, S. Osuwan, J. H. Harwell, and K. J. Haller, Surfactant recovery from water using foam fractionation, Sep Sci Technol. 31(9) (1996) 1233-1258.

[47]. K.S. Tyson, J. Bozell, R. Wallace, E. Peterson, L. Moens, Biomass Oil Analysis, Research Needs and Recommendations. (2004) 510-34796.

[48]. Perry, R. H., Green, D. W., Perry's Chemical Engineers' Handbook, 7th Edn., Vol: 15, McGawHill, New York, USA (2001), pp. 4-14.

[49]. Richter, B. E., Jones, B. A., Ezzell, J. L., Porter, N. L., et al., Accelerated solvent extraction: A technique for sample preparation. Anal. Chem. 68, (1996), 10331039.

[50]. M. Chen et al. Subcritical co-solvents extraction of lipid Eur. J. Lipid Sci. Technol. 114 (2012), 205-212.

[51]. K. Schafer, Accelerated solvent extraction of lipids for determining the fatty acid composition of biological material, Anal. Chim. 358 (1998) 69-77. 